\title{
ANALISIS TINGKAT KEBERHASILAN USAHATANI SAYURAN DI KECAMATAN PERMATA KABUPATEN BENER MERIAH
}

\author{
(Success Rate Analysis Of Vegetables Farming In The Permata District Of Bener \\ Meriah)
}

\author{
Zahraturrahmi $^{1}$, Agussabti ${ }^{1}$, T Makmur ${ }^{1 *}$ \\ ${ }^{1}$ Program Studi Agribisnis, Fakultas Pertanian, Universitas Syiah Kuala
}

\begin{abstract}
Abstrak. Tujuan dari penelitian ini adalah untuk mengetahui tingkat keberhasilan usahatani sayuran dan faktor-faktor apa saja yang mempengaruhi keberhasilan usahatani sayuran di Kecamatan Permata Kabupaten Bener Meriah. Penelitian ini dilakukan di Kecamatan Permata Kabupaten Bener Meriah dengan menggunakan metode survei. Analisis data yang digunakan adalah uji statistik Chi Square dengan menggunakan bantuan program SPSS versi 20 untuk melihat hubungan antara variabel terikat (Dependent variable) dengan variabel bebas (Independent variabel). Hasil penelitian menunjukkan bahwa tingkat keberhasilan usahatani sayuran di Kecamatan Permata Kabupaten Bener Meriah dalam kategori tingkat keberhasilan usahatani sedang dengan nilai skor sebesar 2,10 dengan persentase rata-rata 58,7 \%. Berdasarkan hasil analisis menunjukkan bahwa faktor-faktor yang mempengaruhi keberhasilan usahatani sayuran adalah faktor karakteristik petani $\left(\mathrm{X}_{1}\right)$, faktor modal $\left(\mathrm{X}_{2}\right)$, faktor inovasi $\left(\mathrm{X}_{3}\right)$, dan faktor motivasi petani $\left(\mathrm{X}_{5}\right)$. Sedangkan faktor yang tidak mempengaruhi keberhasilan usahatani adalah faktor peran penyuluh $\left(\mathrm{X}_{4}\right)$ yang dapat dilihat dari nilai $\mathrm{X}^{2}$ hitung $<\mathrm{X}^{2}$ tabel dan pada taraf signifikansi 0,05 nilai Asymp.Sig yang diperoleh adalah 0,526 lebih besar dari 0,05 yang berarti tidak signifikan dan semakin tidak erat pengaruhnya terhadap keberhasilan usahatani sayuran.
\end{abstract}

Kata Kunci : Keberhasilan Usahatani Sayuran, Kepastian Pasar, Produktivitas dan Keberlanjutan Usahatani

\begin{abstract}
The purpose of this study was to assess the success of vegetable farming and the factors that influence the success of vegetables farming in the district of Permata Bener Meriah. This research was conducted in the district of Bener Meriah district Permata using survey methods. Analysis of the data used is the statistical test Chi Square by using SPSS version 20 to see the relationship between the dependent variable (dependent variable) with independent variables (independent variables). The results showed that the success rate of vegetable farming in the district of Bener Meriah district Permata in the category of farming success rate was with a score of 2.10 with an average percentage of $58.7 \%$. Based on the results of the analysis showed that the factors that influence the success of vegetable farming is characteristic factors of farmers $\left(\mathrm{X}_{1}\right)$, capital factors $\left(\mathrm{X}_{2}\right)$, innovation factor $\left(\mathrm{X}_{3}\right)$, and farmer motivation factor $\left(\mathrm{X}_{5}\right)$. While the factors that do not affect the success of the farm is the role of extension factor $\left(\mathrm{X}_{4}\right)$ which can be seen from the $\mathrm{X}_{\text {count }}^{2}<\mathrm{X}_{\text {table }}^{2}$ and at significance level 0.05 Asymp value. Sig obtained was 0,526 greater than 0.05 , which means not significant and increasingly strong influence on the success of vegetables farming.
\end{abstract}

Keywords:Vegetables Farming Success, Market Certainty, Productivity and Business Continuity

*Corresponding author: tmakmur.agric@unsyiah.ac.id 


\section{PENDAHULUAN}

Kabupaten Bener Meriah merupakan salah satu daerah potensi hortikultura sayuran di Aceh dan sentra tanaman cabai dan tomat yang memberi kontribusi penting bagi perekonomian daerah. Berbagai macam jenis sayur mayur tumbuh subur di Kabupaten Bener Meriah, sebagian berupa tanaman sampingan yang hasilnya hanya untuk memenuhi kebutuhan masyarakat sekitar Kabupaten Bener Meriah. Sayur mayur yang banyak dijumpai berupa bawang daun, buncis, seledri, dan sawi. Namun demikian, juga terdapat berbagai jenis sayuran yang produksinya dipasok untuk memenuhi kebutuhan dari kabupaten lain atau provinsi lain yaitu Aceh dan Sumatera Utara. Komoditas tersebut antara lain cabai besar, cabe rawit, kentang, wortel, tomat, bawang merah, bawang putih, kubis, dan lain-lain (BPTP Aceh, 2016).

Adapun produksi tanaman sayuran menurut jenis sayuran di Kabupaten Bener Meriah mulai tahun 2011-2015 terdapat pada Tabel 1.

Tabel 1. Produksi Tanaman Sayuran Menurut Jenis Sayuran di Kabupaten Bener Meriah (Kuintal), Tahun 2011-2015

\begin{tabular}{|c|l|r|r|r|r|r|r|}
\hline No. & Komoditi & \multicolumn{1}{|c|}{2011} & \multicolumn{1}{c|}{2012} & \multicolumn{1}{c|}{2013} & \multicolumn{1}{c|}{2014} & \multicolumn{1}{c|}{2015} & \multicolumn{1}{c|}{ Total } \\
\hline 1 & Bawang Merah & 13468 & 8511 & 9963 & 17016 & 17289 & 66247 \\
\hline 2 & Cabai & 90548 & 44146 & 69539 & 108437 & 152269 & 965304 \\
\hline 3 & Kentang & 59086 & 44395 & 23762 & 81080 & 766831 & 975154 \\
\hline 4 & Kubis & 38396 & 40391 & 35251 & 55789 & 82574 & 252401 \\
\hline 5 & Tomat & 115523 & 56052 & 72675 & 228945 & 202981 & 676176 \\
\hline 6 & Wartel & 18751 & 27693 & 14150 & 22063 & 29991 & 112648 \\
\hline 7 & Bawang Putih & 1586 & 772 & 984 & 1260 & 0 & 4602 \\
\hline
\end{tabular}

Sumber : Badan Pusat Statistik Aceh (diolah), Tahun 2016.

Berdasarkan tabel diatas diketahui bahwasanya perkembangan produksi tanaman sayuran di Kabupaten Bener Meriah dari tahun 2011-2015 mengalami fluktuasi pada setiap jenis sayuran. Seperti bawang merah, pada tahun 2011 produksinya 13.468 kwintal akan tetapi pada tahun 2012 menurun menjadi 8.511 kwintal dan 2013 kembali meningkat menjadi 9.963 kwintal. Adapun produksi tanaman sayuran menurut jenis sayuran yang tertinggi di Kabupaten Bener Meriah adalah kentang dengan jumlah produksi 975.154 kwintal, selanjutnya cabai dengan jumlah produksi 965304 kwintal dan tanaman tomat dengan jumlah produksi 676.176. Selanjutnya produksi tanaman sayuran terendah menurut jenis sayuran di Kabupaten Bener Meriah adalah bawang putih dengan jumlah produksi 4.602 kwintal dan bawang merah dengan tingkat produksi 66.247 kwintal. Khusus 
cabai dan tomat merupakan komoditi yang umum ditanam sepanjang tahun oleh petani di Kabupaten Bener Meriah, sehingga menjamin ketersediaan bahan baku hampir sepanjang tahun (PEMKAB Bener Meriah, 2012).

Menjelang akhir tahun yang lalu dan memasuki awal tahun, merupakan masa-masa sulit bagi petani sayuran khususnya petani tomat di daerah ini, harga komoditi ini di tingkat produsen terpuruk tajam sampai dengan, produk segar dari komoditas ini hanya dihargai Rp 500 - 600 per kilogram, padahal dengan harga tersebut, jangankan berharap untung, untuk kembali modal saja terasa sulit. Anjloknya harga pasar tomat di tingkat produsen saat ini dipengaruhi oleh beberapa hal, antara lain tersendatnya distribusi komoditi ini dari tingkat produsen ke tingkat konsumen akibat terjadinya longsor dan banjir di sebagian jalur distribusi, akibatnya banyak buah tomat yang busuk selama perjalanan dan kualitasnya menurun drastis ketika sampai kepada konsumen, hal itu menyebabkan harganya juga turun secara drastis. Selain itu mulai berproduksinya tomat dari kawasan Brastagi pasca letusan gunung Sinabung, juga menjadi saingan berat bagi produk tomat dari dataran tinggi Gayo. Pasar dan konsumen di kota Medan dan sekitarnya akan lebih memilih produk dari Tanah Karo tersebut.

Di lema yang saatini di alami oleh para petani sayuran di dataran tinggi Kabupaten Bener Meriah, jika mereka terus menanam tomat dan cabai,sementara ini mereka akan terus merugi, tapi jika mereka menghentikan usaha tani mereka maka pasar-pasar potensial akan di isi oleh produk dari luar Kabupaten Bener Meriah dan itu akan mempersempit peluang pasar bagi produk tomat dan cabai dari Kabupaten Bener Meriah (Lintas Gayo, 2015).

Keberhasilan usahatani sayuran pada saat ini maupun pada era ke depan masih tetap akan menjadi salah satu tumpuan utama pembangunan ekonomi di Kabupaten Bener Meriah, karena dalam era globalisasi persaingan akan semakin ketat, sehingga keberhasilan usahatani sayuran harus selalu ditingkatkan dan dikembangkan agar dapat mampu bersaing dan tangguh dalam menghadapi persaingan global. Penelitian ini bertujuan untuk mengetahui tingkat keberhasilan usahatani sayuran serta faktor-faktor apa saja yang mempengaruhi tingkat keberhasilan usahatani sayuran di Kecamatan Permata Kabupaten Bener Meriah.

\section{METODOLOGI PENELITIAN}

Penelitian ini dilakukan di duadesa yang ada di Kecamatan Permata Kabupaten Bener Meriah yaitu Desa Ramung Jaya dan Desa Jelobok. Pemilihan lokasi ini dilakukan secara sengaja (Purposive sampling) dengan pertimbangan bahwa lokasi tersebut merupakan desa yang penduduknya rata-rata bekerja disektor pertanian tanaman sayuran cabai dan tomat yang memiliki produksi tinggi. Objek penelitian ini dikhususkan pada petanisayurancabaidantomat di Kecamatan Permata dikarenakan tanaman cabai dan tomat adalah tanaman

Analisis Tingkat Keberhasilan Usahatani Sayuran di Kecamatan Permata 193

Kabupaten Bener Meriah (Zahraturrahmi, T Makmur, Agussabti)

Jurnal Ilmiah Mahasiswa Pertanian Unsyiah, Vol. 2, No. 3, Agustus 2017: 191-202 
sayuran yang memiliki produksi tertinggi dan ditanam sepanjang tahun oleh petani. Adapunruang lingkup penelitian ini terbatas pada analisis tingkat keberhasilan usahatani sayuran cabai dan tomat di Kecamatan Permata Kabupaten Bener Meriah.

Data yang diperoleh dalam penelitian ini terdiri dari data primer dan data sekunder. Data primer diperoleh berdasarkan pengamatan di lapangan melalui wawancara langsung dengan petani sayuran. Data sekunderdiperolehdarilembaga dan instansi terkait serta ditunjang oleh beberapa literatur, hasil-hasil penelitian sebelumnya dan studi kepustakaan.

Populasi dalam penelitian adalah seluruh petani yang menjalankan kegiatan usahatani sayuran cabai dan tomat di Kecamatan Permata Kabupaten Bener Meriah.Dari seluruh desa di Kecamatan Permata, dipilih 2 desa sebagai sampel dengansecara sengaja (Purposive sampling). Teknik pengambilan sampel dilakukan secara acak sederhana (System random sampling). Arikunto (2010) dalam penentuan sampel apabila kurang dari 100 lebih baik diambil semua hingga penelitiannya merupakan penelitian populasi. Jika jumlah subjeknya besar dapat diambil antara $10-15 \%$ atau 20-55\%. Besarnya sampel yang diambil dalam penelitian ini adalah $10 \%$ untuk petani dalam kelompok mengingat waktu, biaya dan kemampuan peneliti yang terbatas. Jumlah populasi dari 2 desa sampel sebanyak 461 KK petani sayuran di Kecamatan Permata. Sampel yang diambil sebanyak $10 \%$ dari jumlah KK di setiap desa, maka jumlah sampel masingmasing desa yaitu 19 KK di Desa Ramung Jaya dan 27 KK di Desa Jelobok. Jadi, jumlah keseluruhan sampel dari 2 desa tersebut sebanyak $46 \mathrm{KK}$.

Metode analisis yang digunakan dalam penelitian ini adalah uji statistik Chi Square dengan menggunakan bantuan program SPSS versi 20 untuk melihat hubungan antara variabel terikat (Dependent variable) dengan variabel bebas (Independent variabel).

Tingkat keberhasilan usahatani sayuran dibagi menjadi tiga kategori yaitu tinggi, sedang, dan rendah. Untuk mengukur tingkat keberhasilan usahatani sayuran digunakansistem skor. Metode Scoring adalah pemberian nilai berupa angka pada jawaban pertanyaan untuk memperoleh data kuantitatif yang dapat dibedakan kedalam 3 kategori, yaitu:

1. Tingkat keberhasilan tinggi, diberi skor 3

2. Tingkat keberhasilan sedang, diberi skor 2

3. Tingkat keberhasilan rendah, diberi Skor 1

Untuk mengukur kategori tersebut digunakan rumus lebar interval yaitu:

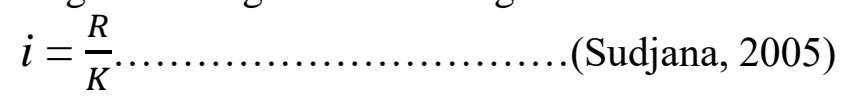

Keterangan :

$i=$ Panjang rentang kelas

$\mathrm{R}=$ Selisih nilai tinggi dengan nilai rendah 
$\mathrm{K}=$ Banyaknya kelas

Jadi :

$$
i=\frac{3-1}{3}=0,66
$$

Kemudian dihitung nilai rata-rata tingkat keberhasilan (y) berdasarkan pembagian antara jumlah rata-rata skor $\sum\left(\mathrm{X}_{1}+\mathrm{X}_{2}+\mathrm{X}_{3}+\mathrm{X}_{4}+\mathrm{X}_{5}\right)$ dengan jumlah variabel (n) berdasarkan rumus:

$$
\mathrm{y}=\frac{X 1+X 2+X 3+X 4+X 5 \ldots X n}{n}
$$

Maka :

1. Skor $1-1,66$ : tingkat keberhasilan rendah

2. Skor $1,67-2,33$ : tingkat keberhasilan sedang

3. Skor 2,34 - 3 : tingkat keberhasilan tinggi

Untuk menguji pengaruh antaravariabel faktor terhadap keberhasilan usahatani sayuran digunakan uji statistik dengan menggunakan Chi-Square (Priyatno, 2005):

$$
\mathrm{X}_{2}=\sum_{i=1}^{k} \frac{(f 0-f h) 2}{f h}
$$

Dimana :

$\mathrm{F}_{0} \quad=$ Banyaknyaobservasi

$\mathrm{F}_{\mathrm{h}} \quad=$ banyaknyaobservasi yang diharapkan

Derajadkebebasan (df) adalah : (jumlah baris-1) (jumlah kolom-1)

Denganketentuan :

Jika $\mathrm{X}_{\text {Hitung }}^{2}>\mathrm{X}_{\text {tabel }^{2}}{ }^{(\mathrm{B}-1)(\mathrm{k}-1)}$, padataraf 0,05 makaterima $\mathrm{H}_{\mathrm{a}}$ tolak $\mathrm{H}_{0}$

Jika $\mathrm{X}_{\text {Hitung }}^{2}<\mathrm{X}_{\text {tabel }}{ }^{(\mathrm{B}-1)(\mathrm{k}-1)}$, padataraf 0,05 makaterima $\mathrm{H}_{0}$ tolak $\mathrm{H}_{\mathrm{a}}$

\section{Hipotesis}

Denganformulasisebagaiberikut:

$\mathrm{H}_{\mathrm{a}}=$ Faktorkarakteristikpetani, modal, inovasi, peran penyuluh, sertamotivasipetaniberpengaruhterhadaptingkatkeberhasilanusahatanisayur an. 
$\mathrm{H}_{0}=$ Faktorkarakteristikpetani, modal, inovasi, peran penyuluh, sertamotivasipetanitidakberpengaruhterhadaptingkatkeberhasilanusahatani sayuran.

\section{HASIL DAN PEMBAHASAN}

Adapun karakteristik petani yang diukur meliputi umur, tingkat pendidikan, jumlah tanggungan, pengalaman usahatani, pendapatan dan jenis komoditi usahatani.

Tabel 2. Rata-rata Karakteristik Petani Sayuran di Kecamatan Permata Kabupaten Bener Meriah Tahun 2016.

\begin{tabular}{|c|l|c|r|}
\hline No & \multicolumn{1}{|c|}{ Karakteristik } & Satuan & \multicolumn{2}{|c|}{ Rata-rata } \\
\hline 1. & Umur & Tahun & 44 \\
\hline 2. & Tingkat Pendidikan & Tahun & 10 \\
\hline 3. & Tanggungan & Jiwa & 24 \\
\hline 4. & Pengalaman Usahatani & Tahun & 12.275 .000 \\
\hline 5. & Pendapatan & Rp/MT & \\
\hline
\end{tabular}

Sumber : Data Primer (Diolah 2016)

\section{Umur}

Tabel 2 menunjukkan bahwa rata-rata umur petani di daerah penelitian adalah 44 tahun, berdasarkan Undang-Undang Tenaga Kerja No. 13 Tahun 2003 yang menyatakan bahwa penduduk yang dikelompokkan sebagai tenaga kerja usia produktif yaitu mereka yang berusia antara 15 tahun sampai 64 tahun. Sehingga dapat disimpulkan bahwa rata-rata petani didaerah penelitian masih tergolong dalam usia produktif untuk bekerja.

\section{Tingkat Pendidikan}

Tingkat pendidikan adalah lamanya waktu yang digunakan oleh petani dalam menempuh pendidikan formal. Rata-rata tingkat pendidikan petani sayuran di daerah penelitian adalah 10 tahun yaitu pada tingkat Sekolah Menengah Atas (SMA). Pendidikan petani merupakan salah satu faktor yang dapat menunjang keberhasilan usahatani. Semakin tinggi tingkat pendidikan yang diperoleh petani maka akan semakin cepat tingkat adopsi teknologi dan inovasi petani, baik yang diterapkan dalam proses pengolahan lahan maupun hingga panen sehingga menunjang keberhasilan usahatani.

\section{Jumlah Tangguan Keluarga}

Jumlah tanggungan keluarga petani sayuran di daerah penelitian rata-rata adalah berjumlah 3 jiwa. Jumlah tanggungan keluarga sangat mempengaruhi pendapatan dan pengeluaran petani. Semakin banyak jumlah tanggungan 
keluarga, maka akan semakin besar biaya hidup yang harus dipenuhi oleh kepala keluarga, maka akan semakin besar biaya hidup yang harus dipenuhi oleh kepala keluarga petani (Oktaviani, 2016).

\section{Pengalaman Usahatani}

Pengalaman berusahatani merupakan salah satu faktor penting bagi petani untuk menjalankan kegiatan usahatani. Ada kecenderungan bahwa semakin banyak belajar dari pengalaman pribadi maupun petani lain yang berhasil tampak semakin lama dalam menjalankan kegiatan usahataninya (Subagio, 2008). Pengalaman berusahatani dalam penelitian ini dilacak dari periode waktu (lamanya) dalam menjalankan kegiatan usahatani dan kemampuan petani dalam menyesuaikan (merubah) jenis tanaman sesuai kebutuhan dan alasan utama menguntungkan menjalankan usahatani.

Hasil penelitian dilapangan menunjukan bahwa rata-rata pengalaman berusahatani petani sayuran adalah 24 tahun. Maka dapat disimpulkan bahwa pengalaman dalam berusahatani mempengaruhi keberhasilan usahatani, karena petani yang memiliki pengalaman yang cukup lama akan cenderung memiliki kemampuan dan keterampilan apabila dibandingkan dengan petani yang kurang berpengalaman.

\section{Pendapatan}

Pendapatan merupakan hasil balas jasa yang diterima petani dari hasil produksi yang diperolehnya. Pendapatan petani di ukur berdasarkan jumlah total penerimaan (Rp) dalam satu kali masim tanam di daerah penelitian yaitu selama 6 bulan. Pendapatan yang diterima oleh petani ini tergantung dari luas lahan dan jumlah modal. Maka rata-rata pendapatan dari usahatani sayuran di Kecamatan Permata adalah sebesar Rp 12.275.000/MT.

\section{Analisis Tingkat Keberhasilan Usahatani Sayuran di Kecamatan Permata Kabupaten Bener Meriah}

Keberhasilan merupakan tujuan inti bagi setiap orang termasuk petani. Keberhasilan usahatani yang hendak dicapai petani adalah suatu kegiatan mulai perencanaan hingga mendapatkan hasil untuk memenuhi kebutuhannya bagi petani sayuran. Dikatakan berhasil bila petani dalam menjalankan usahatani memiliki kepastian pasar dan berkelanjutan untuk menjangkau faktor produksi yang dibutuhkan, dapat menjual hasil dengan harga yang menguntungkan serta dapat meningkatkan produktivitas usahataninya (Subagio, 2008).

Petani di Kecamatan Permata memiliki tingkat keberhasilan yang berbedabeda tergantung dari kondisi lahan dan ekonomi petani. Tingkat keberhasilan usahatani dikategorikan menjadi 3 tingkat yaitu, kategori tingkat keberhasilan usahatani rendah dengan nilai 1-1,66, kategori tingkat keberhasilan usahatani 
sedang dengan nilai 1,67-2,33 dan kategori tingkat keberhasilan usahatani tinggi dengan nilai 2,34-3. Semakin tinggi tingkat keberhasilan usahatani maka tujuan rumah tangga petani akan tercapai semakin baik sehingga tingkat kesejahteraan petani semakin tinggi. Mengenai persentase tingkat keberhasilan usahatani sayuran di Kecamatan Permata Kabupaten Bener Meriah tahun 2016 dapat dilihat pada Gambar 1 di bawah ini.

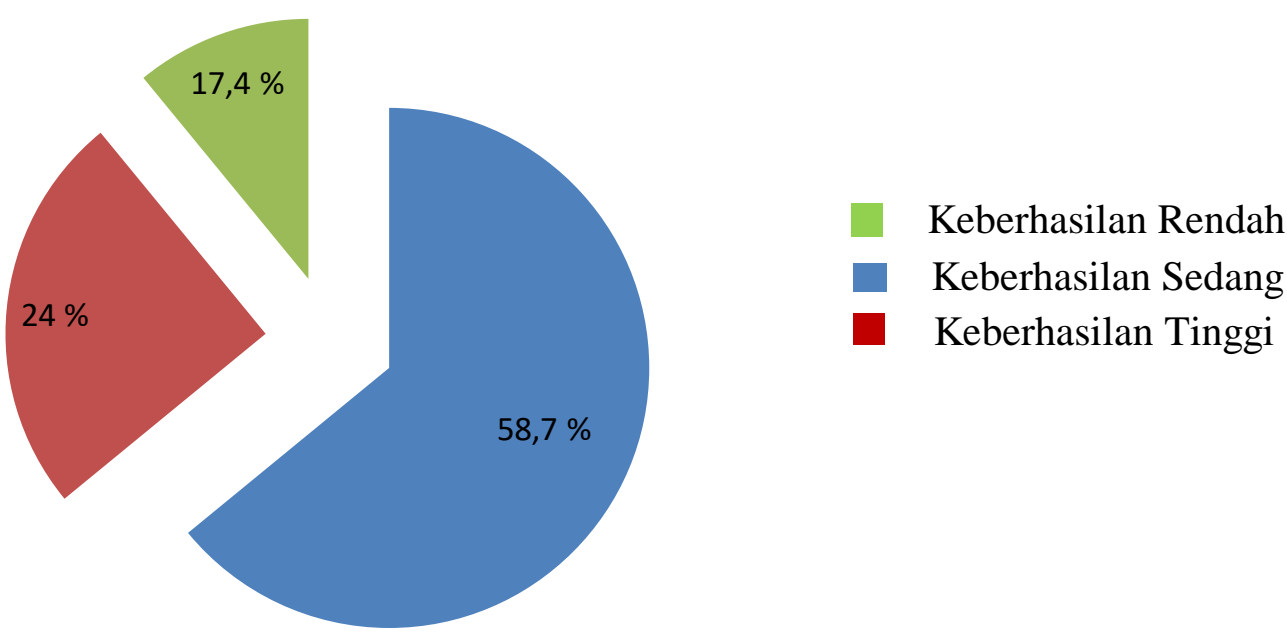

Tingkat Keberhasilan Usahatani Sayuran (\%)

Gambar 1. Persentase Tingkat KeberhasilanUsahataniSayuran di KecamatanPermataKabupatenBenerMeriahTahun 2016

Gambar 1 menunjukkan bahwa persentase tingkat keberhasilan usahatani sayuran di Kecamatan Permata Kabupaten Bener Meriah dalam 3 kategori tingkat keberhasilan usahatani yaitu tingkat keberhasilan usahatani rendah sebesar 17,4 \% dengan total 8 responden, untuk kategori tingkat keberhasilan usahtani sedang sebesar 58,7 \% dengan total 27 responden dan kategori tingkat keberhasilan usahatani tinggi sebesar $24 \%$ dengan total 11 responden. Berdasarkan Gambar 4.1 menunjukkan bahwa tingkat keberhasilan usahatani kategori sedang memiliki persentase paling tinggi dibandingkan dengan kategori lainnya. Sehingga dapat disimpulkan bahwa petani sayuran di Kecamatan Permata Kabupaten Bener Meriah dalam kategori tingkat keberhasilan usahatani sedang dengan nilai skor sebesar 2,10 dengan persentase rata-rata 58,7 \%. 
Tingkat keberhasilan usahatani sayuran dalam penelitian di ukur berdasarkan tiga aspek yaitu aspek kepastian pasar, produktivitas serta keberlanjutan usahatani. Berdasarkan Gambar 1 diketahui rata-rata tingkat keberhasilan usahatani sayuran di Kecamatan Permata dalam kategori tingkat keberhasilan sedang. Hal ini disebabkan berdasarkan aspek kepastian pasar bahwasanya petani sayuran masih menjual produk sayuran langsung kepada pedagang pengumpul didesa dan harga dari sayuran sepenuhnya di tentukan oleh pedagang pengumpul. Selain itu petani juga tidak pernah melakukan promosi produk sayuran keluar desa seperti ke tingkat kecamatan atau kabupaten. Rata-rata kepastian pasar yang dilakukan petani sayuran tampak kurang kondusif.

Berdasarkan aspek produktivitas, dikatakan berproduktivitas tinggi bila petani dalam menjalankan kegiatan usahatani menerapkan prinsip-prinsip efesiensi, memiliki tingkat keuntungan dan mampu memenuhi kebutuhan faktorfaktor produksi secara berkelanjutan. Akan tetapi petani di Kecamatan Permata rata-rata memiliki lahan hanya seluas $0,5-1$ Ha sehingga tingkat produksi sayuran tomat dan cabai tidak terlalu tinggi. Kemudian harga faktor-faktor produksi lebih tinggi dibandingkan dengan harga jual sayuran khususnya tanaman tomat. Sehingga petani sering sekali mengalami kerugian terutama pada saat panen perdana.

Berdasarkan aspek keberlanjutan, rata-rata petani sayuran memiliki perencanaan tetapi perencanaan tersebut tidak rinci dan tidak memiliki titik fokus. Contohnya pada penjualan produk sayuran hanya dijual kepada pedagang pengumpul tanpa adanya perencanaan untuk meningkatkan harga jual produk dengan menjual langsung kepada pedagang besar atau menjual langsung kepada konsumen. Selain itu kurangnya peran pemerintah khususnya dinas pertanian dalam meningkat kapasitas petani sehingga kemampuan dan pengetahuan petani dalam mengembangkan usahatani terbatas. Kemudian petani sayuran dalam menjalankan kegiatan usahataninya rata-rata hanya memakai tenaga kerja yang berasal dari dalam keluarga, hal ini disebabkan jumlah lahan usahatani yang tidak terlalu luas sehingga produktivitas yang dihasilkan juga rendah. Dan minimnya penggunaan inovasi sosial ekonomi dalam menjalankan kegiatan usahatani, petani sayuran lebih dominam menggunakan inovasi teknis dalam melaknakan kegiatan usahatani sehingga terjadinya ketidakseimbangan dalam penggunaan inovasi yang mempengaruhi keberlanjutan usahatani.

\section{Faktor-faktor yang Mempengaruhi Keberhasilan Usahatani Sayuran di Kecamatan Permata Kabupaten Bener Meriah}

Keberhasilan usahatani dipengaruhi oleh beberapa faktor yaitu karakteristik petani, modal, inovasi, peran penyuluh serta motivasi petani. Untuk melihat apakah faktor petani pengelola, modal, inovasi, peran penyuluh dan 
motivasi petani mempengaruhi keberhasilan usahatani sayuran di Kecamatan Permata Kabupaten Bener Meriah dilakukan menggunakan SPSS Statistik versi 20 dengan uji statistik Chi Square. Variabel Keberhasilan Usahatani (Y) menjadi variabel terikat (dependent variable) yang dipengaruhi oleh variabel bebas (independent variable) yaitu karakteristik petani $\left(\mathrm{X}_{1}\right)$, modal $\left(\mathrm{X}_{2}\right)$, inovasi $\left(\mathrm{X}_{3}\right)$, peran penyuluh $\left(\mathrm{X}_{4}\right)$, dan motivasi petani $\left(\mathrm{X}_{5}\right)$. Analisis ini untuk mengetahui bagaimana pengaruh faktor-faktor tersebut terhadap keberhasilan usahatani sayuran di Kecamatan Permata Kabupaten Bener Meriah.

Berdasarkan hasil uji Chi Square terhadap faktor-faktor yang mempengaruhi keberhasilan usahatani sayuran yang telah diuraikan diatas maka dapat dilihat hasil rekapitulasi uji Chi Square terhadap faktor-faktor yang mempengaruhi keberhasilan usahatani sayuran di Kecamatan Permata Kabupaten Bener Meriah pada Tabel 18 di bawah ini.

Tabel 3. Hasil Chi Square Test Terhadap Faktor-faktor yang Mempengaruhi Keberhasilan Usahatani Sayuran

\begin{tabular}{|c|c|c|c|}
\hline Variabel & $\begin{array}{c}\text { Pearson } \\
\text { Chi-Square }\end{array}$ & $D f$ & Asymp.Sig. (2-sided) \\
\hline Karakteristik Petani $\left(\mathrm{X}_{1}\right)$ & $16.648^{\mathrm{a}}$ & 4 & .002 \\
\hline Modal $\left(\mathrm{X}_{2}\right)$ & $68.110^{\mathrm{a}}$ & 4 & .000 \\
\hline Inovasi Petani $\left(\mathrm{X}_{3}\right)$ & $67.593^{\mathrm{a}}$ & 4 & .000 \\
\hline Peran Penyuluh $\left(\mathrm{X}_{4}\right)$ & $3.192^{\mathrm{a}}$ & 4 & .526 \\
\hline Motivasi Petani $\left(\mathrm{X}_{5}\right)$ & $76.109^{\mathrm{a}}$ & 4 & .000 \\
\hline \multicolumn{4}{|c|}{$\mathrm{X}_{\text {tabel }}^{2}$ pada taraf signifikansi 0,05 adalah 9,491} \\
\hline
\end{tabular}

Sumber : Data Primer (Diolah, 2016)

Berdasarkan Tabel 3 diatas dapat disimpulkan bahwa faktor-faktor yang mempengaruhi keberhasilan usahatani sayuran adalah faktor karakteristik petani $\left(\mathrm{X}_{1}\right)$, modal $\left(\mathrm{X}_{2}\right)$, inovasi petani $\left(\mathrm{X}_{3}\right)$, dan motivasi petani $\left(\mathrm{X}_{5}\right)$ yang dapat dilihat dari nilai $\mathrm{X}^{2}$ hitung $>\mathrm{X}_{\text {tabel }}^{2}$ dengan keputusan tolak $\mathrm{H}_{0}$ atau dapat diketahui pula dari nilai Asymp.Sig yang diperoleh adalah lebih kecil dari 0,05 yang berarti signifikan atau faktor karakteristik petani $\left(\mathrm{X}_{1}\right)$, modal $\left(\mathrm{X}_{2}\right)$, inovasi petani $\left(\mathrm{X}_{3}\right)$, dan motivasi petani $\left(\mathrm{X}_{5}\right)$ berpengaruh terhadapa keberhasilan usahatani sayuran di Kecamatan Permata Kabupaten Bener Meriah. Adapun faktor yang tidak mempengaruhi keberhasilan usahatani sayuran adalah faktor peran penyuluh $\left(\mathrm{X}_{4}\right)$ yang dapat dilihat dari nilai $\mathrm{X}^{2}{ }_{\text {hitung }}<\mathrm{X}^{2}$ tabel dengan keputusan yang diambil adalah tolak $\mathrm{H}_{\mathrm{a}}$ atau dapat diketahui pula dari nilai Asymp.Sig yang diperoleh adalah 0,526 lebih besar dari 0,05 yang berarti tidak signifikan. 


\section{KESIMPULAN DAN SARAN}

Berdasarkan hasil penelitian dan pembahasan, maka dapat diambil kesimpulan sebagai berikut:

1. Tingkat keberhasilan usahatani sayuran di Kecamatan Permata Kabupaten Bener Meriah dalam kategori tingkat keberhasilan usahatani sedang dengan nilai skor sebesar 2,10 dengan persentase rata-rata sebesar 58,7.

2. Adapun faktor-faktor yang mempengaruhi keberhasilan usahatani sayuran adalah faktor karakteristik petani $\left(\mathrm{X}_{1}\right)$, faktor modal $\left(\mathrm{X}_{2}\right)$, faktor inovasi $\left(\mathrm{X}_{3}\right.$, dan faktor motivasi petani $\left(\mathrm{X}_{5}\right)$. Sedangkan faktor yang tidak mempengaruhi keberhasilan usahatani adalah faktor peran penyuluh $\left(\mathrm{X}_{4}\right)$.

Berdasarkan hasil penelitian, disarankan kepada dinas pertanian program penyuluhan yang diselenggarakan merupakan program petani (sasaran), substansi penyuluhan berbasis kebutuhan petani, mengikuti kaidah proses belajar orang dewasa, model komunikasi konvergen/interaktif, dan melibatkan semua kalangan petani baik laki-laki maupun perempuan. Dan diharapkan kepada petani sayuran agar mempunyai kesadaran akan pentingnya mengikuti penyuluhan pertanian yang dilaksanakan oleh dinas pertanian untuk meningkatkan kapasitas petani dalam mewujudkan keberhasilan usahatani sayuran di Kecamatan Permata Kabupaten Bener Meriah.

\section{DAFTAR PUSTAKA}

Agussabti. 2002. Kemandirian Petani Dalam Pengambilan Keputusan Adopsi Inovasi Petani Sayuran Di Jawa Barat. Disertasi. Program Pascasarjana. Bogor: Institut Pertanian Bogor.

Arikunto, S. 2002. Prosedur Penelitian, Suatu Pendekatan dan Praktek. PT. Rineka Cipta. Jakarta.

Badan Pusat Statistika. 2012. Dinas Pertanian Tanaman Pangan Bener Meriah Provinsi Aceh.

Indriyatni, L. 2013. Analisis Faktor-faktor yang Berpengaruh Terhadap Keberhasilan Usaha Mikro dan Kecil(Studi Pada Usaha Kecil Di Semarang Barat). STEI Pelita Nusantara, Semarang.

Kementrian Pertanian. 2016. Balai Pengkajian Teknologi Pertanian (BPTP) Aceh. Badan Penelitian dan Pengembangan Pertanian.

Puslibang Sosek [Pusat Penelitian dan Pengembangan Sosial Ekonomi Pertanian]. 2004. Himpunan Berbagai Pikiran Tentang Pembangunan Pertanian Periode 2005-2020. Analisis Kebijakan Pertanian Vol.(2) 4. Bogor: Pusat Penelitian dan Pengembangan Sosial Ekonomi Pertanian.

Puspadi, K. 2002. Rekonstruksi Sistem Penyuluhan Pertanian. Disertasi. Program Pasca Sarjana Institut Pertanian Bogor. 
Rogers dan Soemaker. (Eds). 1987. Memasyarakatkan Ide-ide Baru. Surabaya: Usaha Nasional.

Slamet, M. 1987. "Memantapkan Penyuluhan Pertanian di Indonesia" . Makalah di sampaikan pada Kongres Penyuluhan Pertanian di Subang tanggal 4-6 Juli1987.

Slamet, M., 2006. Paradigma Baru Penyuluhan Pertanian di Era Otonomi Daerah. Makalah disajikan dalam Pelatihan Penyuluhan Pertanian di Universitas Andalas. Juli 2006.

. 1995. "Sumbang Saran Mengenai Pola Strategi dan Pendekatan Penyelenggaraan Penyuluhan Pertanian pada PJP II'. Makalah disampaikan pada Lokakarya Dinamika dan Perspektif Penyuluhan Pertanian pada PJP II di Bogor, tanggal 4 - 5 Juli 1995.

_ . 2003. "Pemberdayaan Masyarakat." DalamMembentuk Pola PerilakuManusia Pembangunan. Disunting oleh Ida Yustina dan Adjat Sudradjat. Bogor: IPB Press.

Subagio, H. 2008. Peran Kapasitas Petani dalam Mewujudkan Keberhasilan Usahatani : Kasus Petani Sayuran dan Padi di Kabupaten Malang dan Pasuruan Provinsi Jawa Timur. Sekolah Pascasarjana IPB. Bogor.

Soekartawi. 2002. Prinsip Dasar Ekonomi Pertanian Teori dan Aplikasi. PT. Raja Grafindo. Jakarta.

Soekartawi. 1998. Prinsip Dasar Ekonomi Pertanian. UI Press. Jakarta.

Young D. L. 1979. Risk Preference of Agricultural Producers: Their Use in Extension and Research.American Journal Agricultural Economics. Vol. 61. 